\title{
Climate, RAIN SHADOW, AND HUMAN-USE INFLUENCES ON FIRE REgIMES IN THE EASTERN SIERRA NEVADA, CALIFORNIA, USA
}

\author{
Malcolm P. North ${ }^{1,2, *}$ Kip M. Van de Water ${ }^{2}$, Scott L. Stephens ${ }^{3}$, and Brandon M. Collins ${ }^{3}$ \\ ${ }^{1}$ USDAForest Service, Pacific Southwest Research Station, \\ 1731 Research Park Drive, Davis, California 95618, USA \\ ${ }^{2}$ Department of Plant Sciences, \\ One Shields Avenue, University of California, Davis, California 95616, USA \\ ${ }^{3}$ Division of Ecosystem Sciences, \\ Department of Environmental Science, Policy and Management, \\ 137 Mulford Hall, University of California, Berkeley, California 94720, USA \\ *Corresponding author: Tel.: 001-530-754-7398; e-mail: mpnorth@ucdavis.edu
}

\begin{abstract}
There have been few fire history studies of eastern Sierra Nevada forests in California, USA, where a steep elevation gradient, rain shadow conditions, and forest stand isolation may produce different fire regimes than those found on the range's western slope. We investigated historic fire regimes and potential climate influences on four forest types ranging in elevation from $1700 \mathrm{~m}$ to $3200 \mathrm{~m}$ on the Sierra Nevada's eastern slope and the White Mountains' western slope. Sample areas (approximately 15 ha to 45 ha) had mean site fire return intervals ranging from $4.8 \mathrm{yr}$ to $16.9 \mathrm{yr}$ across ten Jeffrey pine (Pinus jeffreyi Balf.) sites, and $13.4 \mathrm{yr}$ to $45.7 \mathrm{yr}$ across four high elevation lodgepole ( $P$. contorta Douglas ex Louden), foxtail (P. balfouriana Balf.) and bristlecone (P. longaeva D.K. Bailey) pine sites. At most sites (13 of 14), $>50 \%$ of fire events occurred in late or dormant season wood. Twentieth century fire return intervals increased at some sites, while other sites continued to record frequent fire events into the 1950s. Years where two or more sites recorded fire events on two or more trees were correlated with drought conditions forecast by the Palmer Drought Severity Index (PDSI) in our sample locations at and north of Mammoth Lakes. The lower Sierra Nevada crest due west of these locations may connect weather patterns with western slope conditions more than at our southern eastside sample sites, which were not significantly correlated with PDSI. Our results suggest eastern Sierra Nevada Jeffrey pine forests have similar seasonality and fire return intervals as some western slope forests, but site fire history can be influenced by stand isolation, historical use, and local rain shadow conditions.
\end{abstract}

Keywords: dendrochronology, fire climate interactions, fire frequency, Jeffrey pine forests

Citation: North, M.P., K.M. Van de Water, S.L. Stephens, and B.M. Collins. 2009. Climate, rain shadow, and human-use influences on eastern Sierra Nevada fire regimes. Fire Ecology 5(3): 20-34. doi: 10.4996/fireecology.0503020 


\section{INTRODUCTION}

For centuries, fire has strongly affected the structure, composition, and ecological processes of many western United States forests (Pyne 1982, Skinner and Chang 1996). In some forests following European settlement in the nineteenth century, the frequency and extent of fire diminished rapidly as climate, grazing practices, and eventually fire suppression altered fire ignitions and patterns (Douglass and Bilbao 1975, Anderson and Moratto 1996, Millar and Wolfenden 1999). Consequently, productive forests with frequent, low-intensity fire regimes have accumulated fuels, increasing fire hazard and intensity when inevitable ignitions occur (McKelvey and Busse 1996, Stephens and Moghaddas 2005). Fire histories have been completed for the Tahoe Basin (Taylor 2004, Beatty and Taylor 2008) and forest types along the Sierra Nevada's western slope including ponderosa pine (Pinus ponderosa C. Lawson) (Caprio and Swetnam 1995), mixed conifer (Kilgore and Taylor 1979, Stephens and Collins 2004, North et al. 2005), red fir (Abies magnifica A. Murray) (Pitcher 1987, Taylor 1993) and giant sequoia (Sequoiadendron giganteum [Lindl.] J. Buchholz) (Swetnam 1993). Forests of the eastern Sierra Nevada, particularly those toward the southern portion of the range, are not as well researched (but see Stephens 2001, Vaillant and Stephens 2009). As such, managers often rely on fire histories from westside Sierra Nevada studies (Michelle Slaton, Inyo National Forest, personal communication).

Many fire history studies have found correlations between drier and warmer years recorded in different climate indices such as the El Niño Southern Oscillation (ENSO) and Pacific Decadal Oscillation (PDO), and fire scarring recorded across widespread tree samples (Grissino-Mayer and Swetnam 2000, Kitzberger et al. 2007, Heyerdahl et al. 2008, Skinner et al. 2008). California's winter precipita- tion can vary tenfold or more between wet and dry years associated with ENSO cycles between El Niño and La Niña events. Typically, winter storms move from west to east across the Sierra Nevada, generally linking the two weather patterns but with the eastside generally drier. However, during some summers, the eastern Sierra Nevada experiences limited monsoonal rains that are common in southwestern ponderosa pine forests (Powell and Klieforth 2000).

Eastern Sierra Nevada forests may have significantly different fire history patterns than forests on the western slope due to steep topography, forest isolation, and different human-use practices. Steep topographic relief along the eastern slope compresses gradients in forest community change. Compared to the western slopes' large contiguous forests, eastern Sierra Nevada forests are often isolated in canyons or on benches in discrete stands that can affect fire return interval (Arabas et al. 2006). In addition, anthropological studies suggest regional differences between east- and west-slope Native American tribes in their use of fire to clear the forest (Weaver and Basgall 1986, Blake and Wagner 1987). These factors combined suggest that characterizations of historical fire regimes from the western slope of the Sierra Nevada may not be applicable for guiding management of east-slope forests.

The objective of this study was to reconstruct historical fire regimes across an elevational gradient of forest communities in the eastern Sierra Nevada. We hypothesized that: 1) fire return interval would increase with sample stand elevation and isolation, 2) fire season relative to tree growth would not significantly differ from western slope forests, 3) fire return interval would increase from the late nineteenth century on, and 4) fires would be more frequent in the same year that dry La Niña weather conditions occur. Our goal was to sample a broad range of forest communities and stand physiographic conditions to assess 
the variability in eastern Sierra Nevada historic fire regimes.

\section{METHODS}

We focused our sampling on the area encompassed by forests east of the Sierra Nevada and west of the White and Inyo mountain crests in California, USA. Although vegetation in the White and Inyo mountains is considered part of the Great Basin floristic province (Barbour and Major 1990), the scattered forests on the ranges' western slopes have some similarities to Sierra Nevada eastern slope forests (Elliot-Fisk and Peterson 1991). For simplicity we have grouped these sites with our other sample stands and will refer to them as eastern Sierra Nevada. This region, in the rain shadow of the storms moving east from the Pacific Ocean, has a steeper elevation grade than the western slope of the Sierra Nevada, in some places dropping more than 2500 $\mathrm{m}$ in less than $10 \mathrm{~km}$. Most precipitation occurs as snow and ranges from approximately $2000 \mathrm{~mm}$ per year at Sierraville in the north to about $500 \mathrm{~mm}$ per year at Whitney Portal in the south (Figure 1). Soils vary considerably across the region but in general are weakly developed and excessively well drained on decomposed granite; however, local islands of fertility are present in some forests (Johnson et al. 2009). Forest type changes with elevation and precipitation gradients but often consists of foxtail (Pinus balfouriana Balf.) and lodgepole pine (Pinus contorta Douglas ex Louden ssp. murrayana [Balf.] Critchfield) near treeline; red fir and white fir (Abies concolor [Gord. \& Glend.] Lindl. ex Hildebr.), mixed conifer, or Jeffrey pine (P. jeffreyi Balf.) at mid elevations; and pinion pine ( $P$. edulis Engelm) and sagebrush (Artemesia spp. L.) or agricultural fields on the valley floor. In general, forest stands are often isolated in canyons or on ridges surrounded by talus and cliffs in the southern part of the study area, while from
Mammoth Lakes to the north, more extensive forests of Jeffrey pine are common. Early European settlement, after the $1860 \mathrm{~s}$, was concentrated in a few mountainous boom mining areas such as Bodie, Aurora, Cerro Gordo, and cattle ranches on the valley floor. Sheep grazing was common in the alpine country of Sierra Nevada after 1880 , but there are no historical accounts of grazing in the forest communities that we sampled.

Site selection was not random and varied between northern and southern areas of the eastern Sierra Nevada. South of Bridgeport, sample site selection was constrained by a lack of road access and the lower extent of many forests occurring within wilderness areas that limit chainsaw use. For sites on the Inyo $\mathrm{Na}-$ tional Forest, we first consulted Forest Service GIS databases and personnel familiar with local forest conditions to identify potential sample sites. We visited sites that were not in wilderness and assessed the potential age of forest structures (estimated by relative size) and the abundance of visible fire scars. For the Bridgeport and Sierraville locations, we selected remnant old-growth stands to assist in forest demography reconstructions in this area of the eastern Sierra Nevada.

We selected 14 stands ranging in elevation from $1616 \mathrm{~m}$ to $3181 \mathrm{~m}$, and $118^{\circ} 9^{\prime}$ to $120^{\circ} 22^{\prime}$ longitude and $37^{\circ} 32^{\prime}$ to $39^{\circ} 35^{\prime}$ latitude (Figure 1). Ten of the 14 stands are in Jeffrey pine forest, one in foxtail pine, one in a mix of foxtail and lodgepole pine, one in lodgepole only, and one in bristlecone pine (Pinus longaeva D.K. Bailey). At the bristlecone site adjacent to the Schulman Grove, we only sampled old stumps left from trees cut in the 1870 s for the Mexican Mine. We attempted to locate mixed-conifer and true fir sample sites but were either limited by the wilderness boundary or by the absence of visible fire scars at potential sample locations. Unlike some other landscape studies where forest 'island' and 'mainland' fire histories have been compared (Madany and 


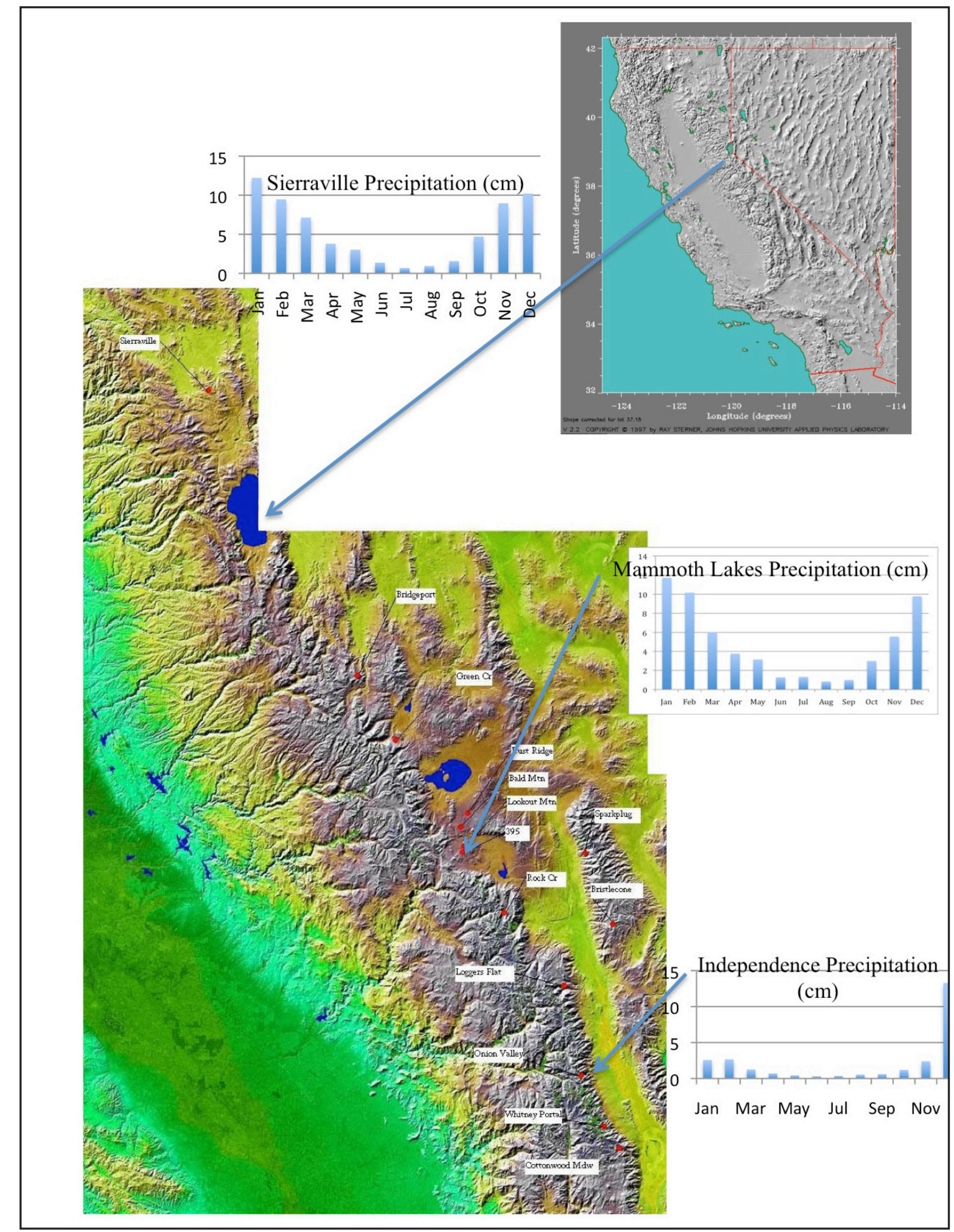

Figure 1. Location of the sample area in California (upper right) and a shaded relief map of the 14 sample sites in the eastern Sierra Nevada. The three inset graphs show mean monthly precipitation $(\mathrm{cm})$ for Sierraville, Mammoth Lakes, and Independence. 
West 1983, Grissino-Mayer and Swetnam 1995, Clarke 2002, Arabas et al. 2006), many forest stands in the eastern Sierra Nevada are isolated in canyons or on ridge tops surrounded by a matrix of light fuels (e.g., sagebrush steppe) or no fuels (talus and cliffs). We classified nine of our sample stands (Bristlecone, Rock Creek, Cottonwood Meadow, Onion Valley, Loggers Flat, Rust Ridge, Whitney Portal, Green Creek, and Sparkplug) as isolated because they were all in forests $<200$ ha in size with the next nearest forest also being an isolated stand and $>2 \mathrm{~km}$ distant. The remaining five sample sites are all Jeffrey pine stands that are either part of the large, contiguous forest belt east of Mammoth Lakes (Bald Mountain, 395, Lookout Mountain) or on broad forested plateaus (Bridgeport, and Sierraville).

At each site, we surveyed an area of approximately 40 ha, except at the Sierraville and Bridgeport sites (20 ha) where collection was limited to areas within and adjacent to old-growth Jeffrey pine stands. We prioritized our sample, preferentially selecting trees that appeared to record multiple fire events (Swetnam and Baisan 2003), particularly larger trees that potentially had a longer record. We sampled dead material (i.e., stumps, snags, and logs) if available, before sampling live trees. On dead material, we collected a full crosssection. On live tree 'catface' scars we extracted a wedge of wood from tree center out to the bark (Arno and Sneck 1977).

In the lab, we sanded all samples with progressively finer sand paper, and using standard crossdating procedures (Stokes and Smiley 1977), dated all fire scars under a binocular microscope. We estimated the season of each fire event by classing each fire scar as occurring in earlywood (early, middle, or late), latewood, or dormant season (Dieterich and Swetnam 1984). The FHX2 software (GrissinoMayer 2001) was used to record and analyze fire scar data. For each site, we used two composite scales or filters. Our broad composite
(C1) included all samples that recorded a scar in an effort to provide a more comprehensive record of fire events at each sample site. We also used a more restricted filter $(\mathrm{C} 10)$ that only included fire events scarring a minimum of two trees or $10 \%$ of the samples in an effort to remove relatively small fires (Swetnam and Baisan 1996). Sites had different time periods over which scars appeared in samples. For each site, we restricted our fire return interval analysis to periods starting when two trees had each recorded at least one scarring event.

To examine potential correlations between fire events and climate, we identified years in which two or more trees at a site were scarred, and two or more sites recorded scars in the same year (Dieterich 1980). Most of our sample sites are widely separated by areas with minimal fuel. Therefore, we did not assume that these scars at different sites were produced by a common fire; rather, that climate conditions may have favored more fire events that year. We used superposed epoch analysis (SEA) and two climate proxy indices to compare climate for six years prior to, the year of, and four years after each year in which fire occurred at two or more sites (Swetnam 1993). We used data from gridpoint 59 (nearest our sample sites) from the reconstructed Palmer Drought Severity Index (PDSI) (Cook et al. 1999). The PDSI drought years have been associated with fire events in several studies on the western slopes of the Sierra Nevada (Norman and Taylor 2003, Swetnam and Baisan 2003, Stephens and Collins 2004, Taylor and Beaty 2005). We also examined the NINO3 index (Cook 2000), a measure of mid-tropical Pacific sea surface temperatures correlated with the El Niño Southern Oscillation (ENSO). The ENSO has been shown to be associated with fire events in the southwestern US (Grissino-Mayer and Swetnam 2000, Skinner et al. 2008), parts of the Sierra Nevada (Norman and Taylor 2003, Beaty and Taylor 2008), and the Pacific northwest (Kitzberger et al. 2007, Hey- 
erdahl et al. 2008). We used ENSO to examine whether monsoonal rain patterns affecting the southwest might also influence eastern Sierra Nevada fire regimes. We standardized values in both indices around a mean of zero. Monte Carlo simulations (1000 iterations) were used to calculate $99 \%$ confidence intervals.

\section{RESULTS}

From the 14 sample sites (Table 1), 18 tree cross-sections of the total 182 sections collected could not be crossdated (many from Bald Mountain) and were not used in the analysis. The period of record ranged from 1039, the earliest ring on a foxtail pine at Onion Valley, to 2008, the last year of collection (Figure 2). The samples contained a total of 694 scars, with the earliest recording a fire in 1161 on a bristlecone pine sample, and the latest recording a fire in 1999 on a lodgepole pine sample from Green Creek (Figure 3).
Mean site fire interval $(\mathrm{C} 1)$ varied from 4.8 $\mathrm{yr}$ in one Jeffrey pine site (395) to $45.7 \mathrm{yr}$ in the bristlecone pine site (Table 1). Across all Jeffrey pine sites, the average site interval was 10.9 yr. Using a Spearman rank correlation analysis, there was no significant $(p<0.05)$ correlation between site fire interval and elevation. Using a more restricted filter (C10), the fire interval for fires scarring two or more trees varied from $8.9 \mathrm{yr}$ at the 395 site (Jeffrey pine) to $38.7 \mathrm{yr}$ at Cottonwood Meadow (lodgepole and foxtail pine). A C10 fire return interval could not be calculated from the bristlecone pine samples because only one fire event was recorded in the same year on two or more trees.

Many fire histories in the western US have documented a modern period of reduced fire activity toward the end of the nineteenth century. Two of our sites (14\% of the total), Green Creek and Bridgeport, share this pattern, having few fire scars after 1880 and 1890,

Table 1. Sample site name, number of samples in parentheses, forest type, site elevation, aspect, sample size area, time period over which fire interval was calculated, $\mathrm{C} 1$ and $\mathrm{C} 10$ fire return intervals. Forest type abbreviations are bristlecone pine (PILO), lodgepole pine (PICO), foxtail pine (PIBA) and Jeffrey pine (PIJE). C1 is calculated from all scars at a site after two trees are scarred. C10 is the fire return interval calculated from events that scar two or more trees or $10 \%$ of the samples.

\begin{tabular}{lccccccc}
\hline \multicolumn{1}{c}{ Site name } & Forest type & $\begin{array}{c}\text { Elevation } \\
(\mathbf{m})\end{array}$ & Aspect & $\begin{array}{c}\text { Sample } \\
\text { area (ha) }\end{array}$ & $\begin{array}{c}\text { Period of } \\
\text { F.I. analysis }\end{array}$ & $\begin{array}{c}\text { C1 } \\
\text { F.I. }\end{array}$ & $\begin{array}{c}\text { C10 } \\
\text { F.I. }\end{array}$ \\
\hline Bristlecone (10) & PILO & $3107-3181$ & NW & 28 & $1460-1871$ & 45.7 & NA \\
Rock Creek (10) & PICO & $3044-3077$ & SE & 18 & $1676-2006$ & 18.6 & 19.0 \\
Cottonwood Mdw (14) & PICO/PIBA & $3021-3074$ & SE & 44 & $1490-2008$ & 27.2 & 38.7 \\
Onion Valley (13) & PIBA & $2884-2975$ & NW & 18 & $1578-2008$ & 13.4 & 27.8 \\
Loggers Flat (12) & PIJE & $2805-2917$ & E & 45 & $1687-2006$ & 8.0 & 15.9 \\
Whitney Portal (10) & PIJE & $2539-2598$ & SE & 25 & $1739-2008$ & 16.7 & 29.3 \\
Bridgeport (21) & PIJE & $2420-2600$ & E & 20 & $1663-2004$ & 6.8 & 11.7 \\
Bald Mtn (5) & PIJE & $2438-2446$ & NW & 15 & $1816-1990$ & 16.9 & 18.0 \\
Green Cr. (10) & PIJE & $2427-2445$ & NW & 24 & $1756-2008$ & 16.7 & 20.2 \\
Rust Ridge (9) & PIJE & $2381-2433$ & NW & 19 & $1634-2008$ & 10.6 & 36.0 \\
395 (14) & PIJE & $2331-2449$ & NE & 22 & $1770-1985$ & 4.8 & 8.9 \\
Lookout Mtn (8) & PIJE & $2320-2344$ & NW & 15 & $1791-2006$ & 6.5 & 12.6 \\
Sparkplug (8) & PIJE & $2104-2253$ & W & 18 & $1716-2008$ & 11.7 & 31.4 \\
Sierraville (20) & PIJE & $1730-1800$ & N & 40 & $1616-2003$ & 8.2 & 17.8 \\
\hline
\end{tabular}




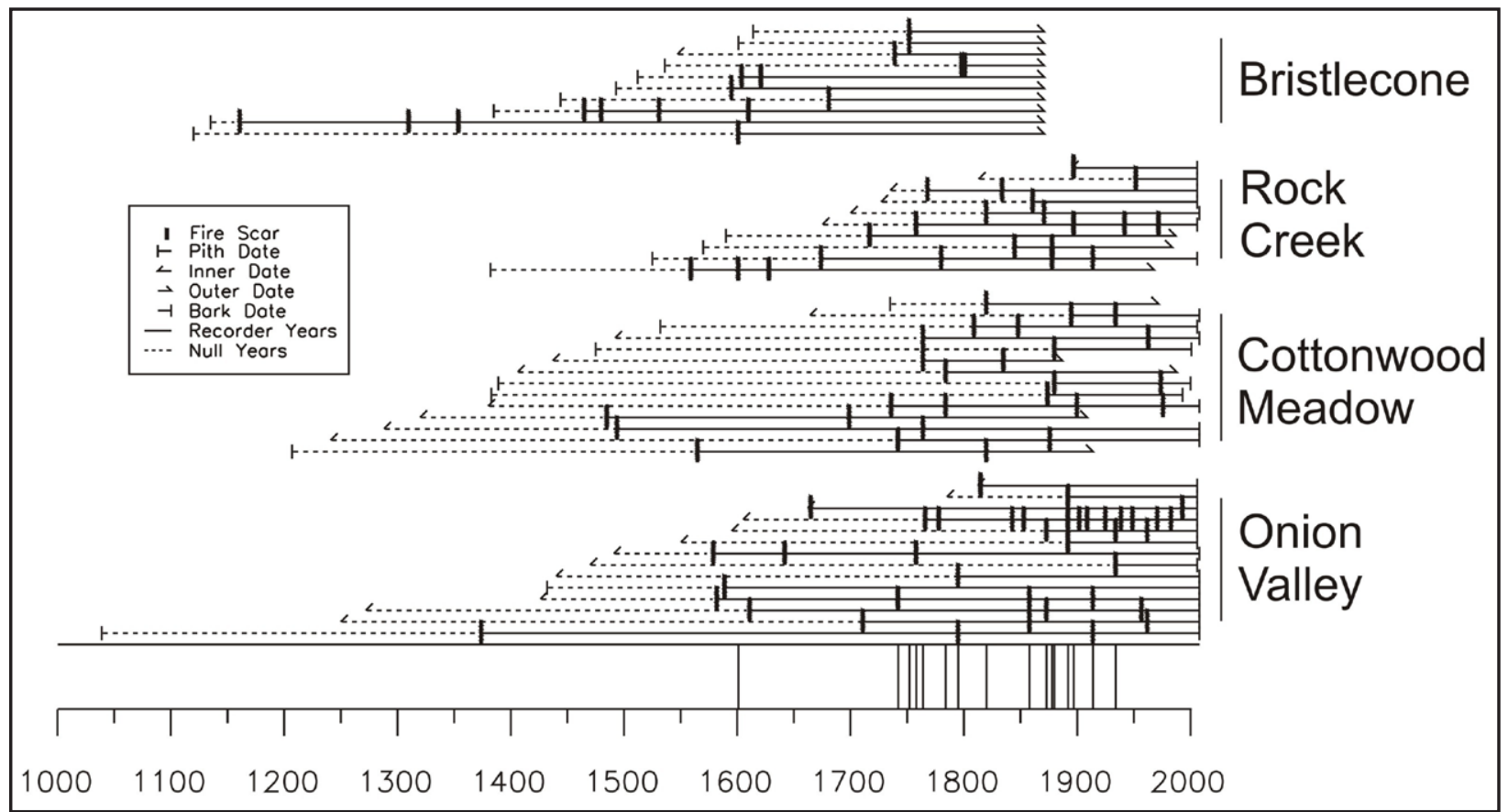

Figure 2. Fire year chronology for the four high elevation $(>3000 \mathrm{~m})$ sample sites containing bristlecone, lodgepole and foxtail pine. Horizontal lines mark the time spans of individual trees with dash portions indicating the period before the first fire scar. Fire scars are designated by vertical tick marks. The composite fire chronology at the bottom of the figure shows years when two or more scars occurred in the same year.

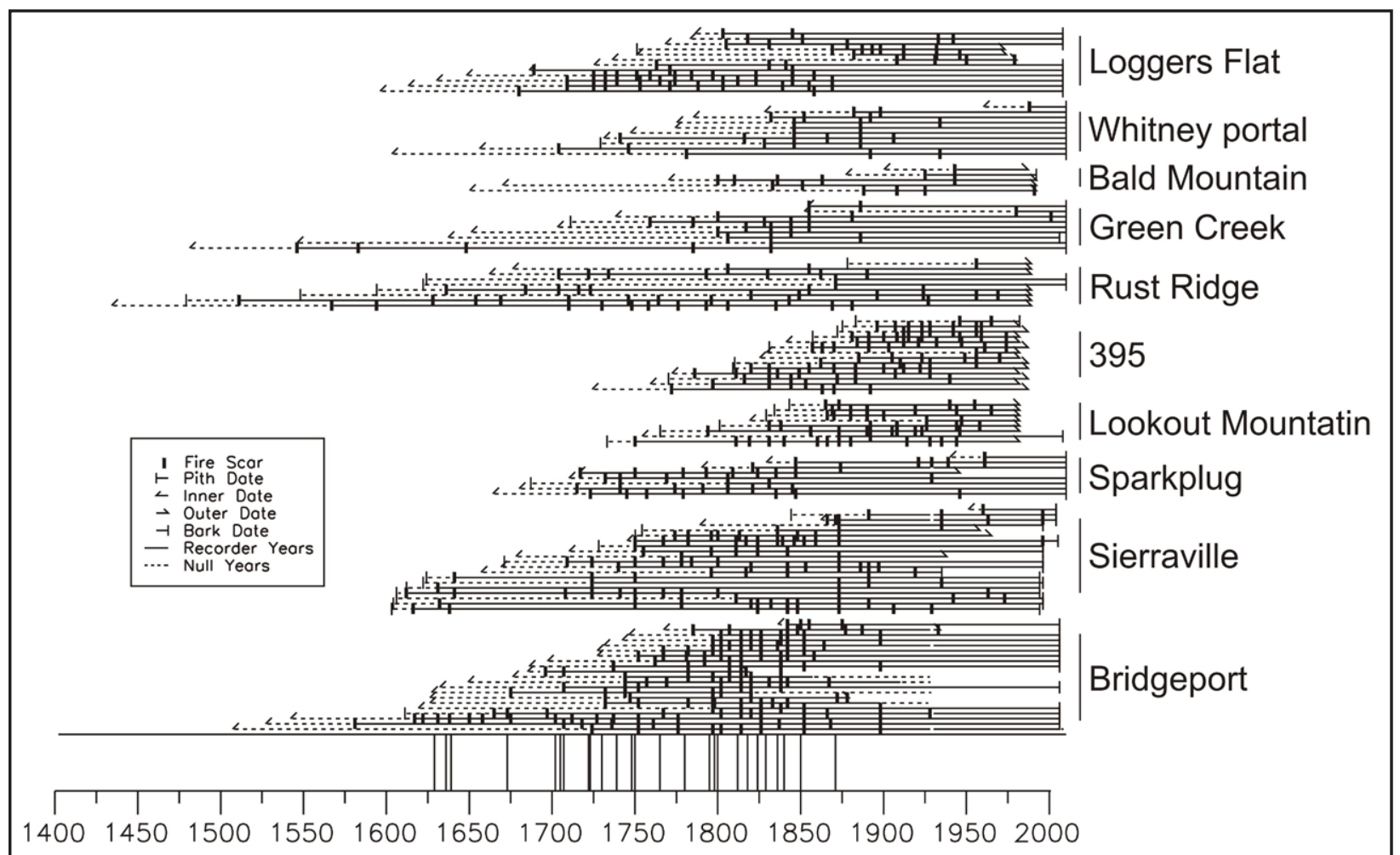

Figure 3. Fire year chronology for the ten lower elevation sample sites containing Jeffrey pine. The composite fire chronology at the bottom of the figure shows years when two or more scars occurred in the same year. 
respectively. The remaining sample sites, however, all have some fire scarring into the 1950s, after which few samples were scarred (Figure 3). For these sites, there was no significant difference in mean site fire return interval between 1700 and 1880 (the beginning of more extensive European settlement) and 1881 to 1960 (Kruskal-Wallis test, $p>0.1$ ).

Seasonality varied with site but, with the exception of Onion Valley (foxtail pine), $\geq 55 \%$ of the scars were either in latewood or the dormant season (Figure 4). The percentage of scars in earlywood at Rock Creek (45\%) and Onion Valley (65\%) was surprising given the elevation and potential for snow cover during the earlywood growth period at these two sites.

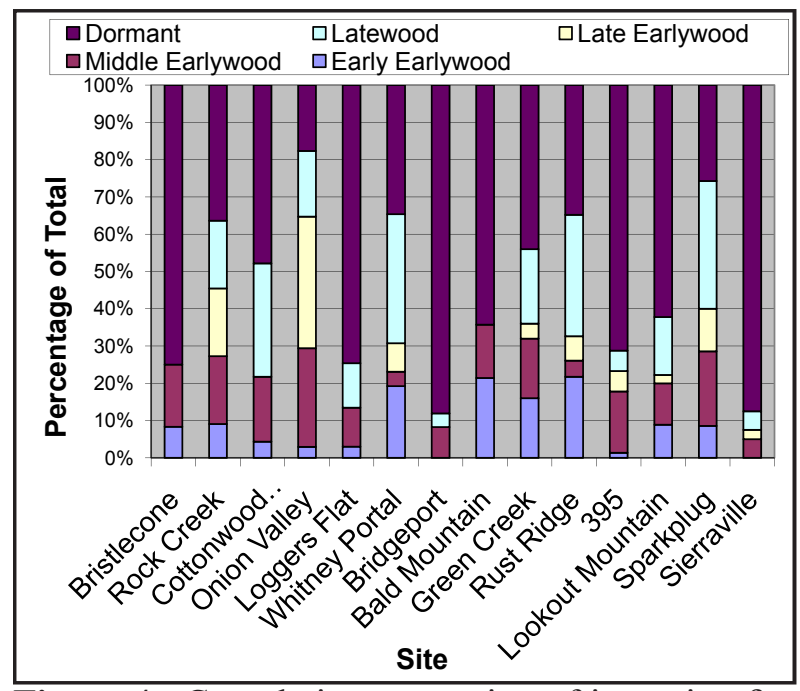

Figure 4. Cumulative proportion of intra-ring fire scar positions for all trees at each of the 14 sample sites.

Filtering the fire scar record for two or more scars in the same year (site records in Figure 5) occurring at two or more sites (the composite in Figure 5) identified a common fire activity pattern between all the Sierra Nevada sites north of Loggers Flat except Bald Mountain (possibly due to the site's small sample size). The SEA of these sites and the NINO3 index did not identify any significant correlation between preceding, current, or post climate conditions and fire events (not shown). Using this same subset of sites, SEA with PDSI did identify a significant association between climate and fire events in the same year, but no patterns between preceding or postevent years (Figure 6).

\section{DISCUSSION}

Fire history of the sites we sampled shared many characteristics of western slope Sierra Nevada forests; however, there were a few important differences. Similarities included: 1) variation in fire return interval across forest types (Caprio and Swetnam 1995, Swetnam et al. 2000); 2) greater proportion of scars occurring in latewood and dormant ring positions (Stephens and Collins 2004, Taylor and Beaty 2005, Moody et al. 2006); and 3) average Jeffrey pine site fire return intervals within the range of those reported for western slope ponderosa pine (Caprio and Swetnam 1995, McKelvey et al. 1996) and Tahoe Basin Jeffrey pine forests (Taylor 2004). Important differences evident from our eastern slope sites were: 1) no strong climate signal throughout (e.g., only fire dates in northern sites coincided with drought, while southern sites demonstrated little connection with climatic indices), and 2) the period of reduced fire activity in many sites did not start until the late 1950s.

Fire return intervals usually increase with elevation, not only due to cooler, moister conditions, but also due to lower productivity and a longer time to accumulate fuels (Martin et al. 1979, Miller and Urban 1999, Swetnam et al. 2000). Our fire scar collection was predominantly from Jeffrey pine sites with only a few higher elevation forest communities, making it difficult to infer the influence of environmental conditions compared to forest type on eastern Sierra Nevada fire regimes. Stephens (2001) suggested that the $15 \mathrm{yr}$ difference in fire return interval he found between adjacent red fir and Jeffrey pine stands near Mammoth Lakes 


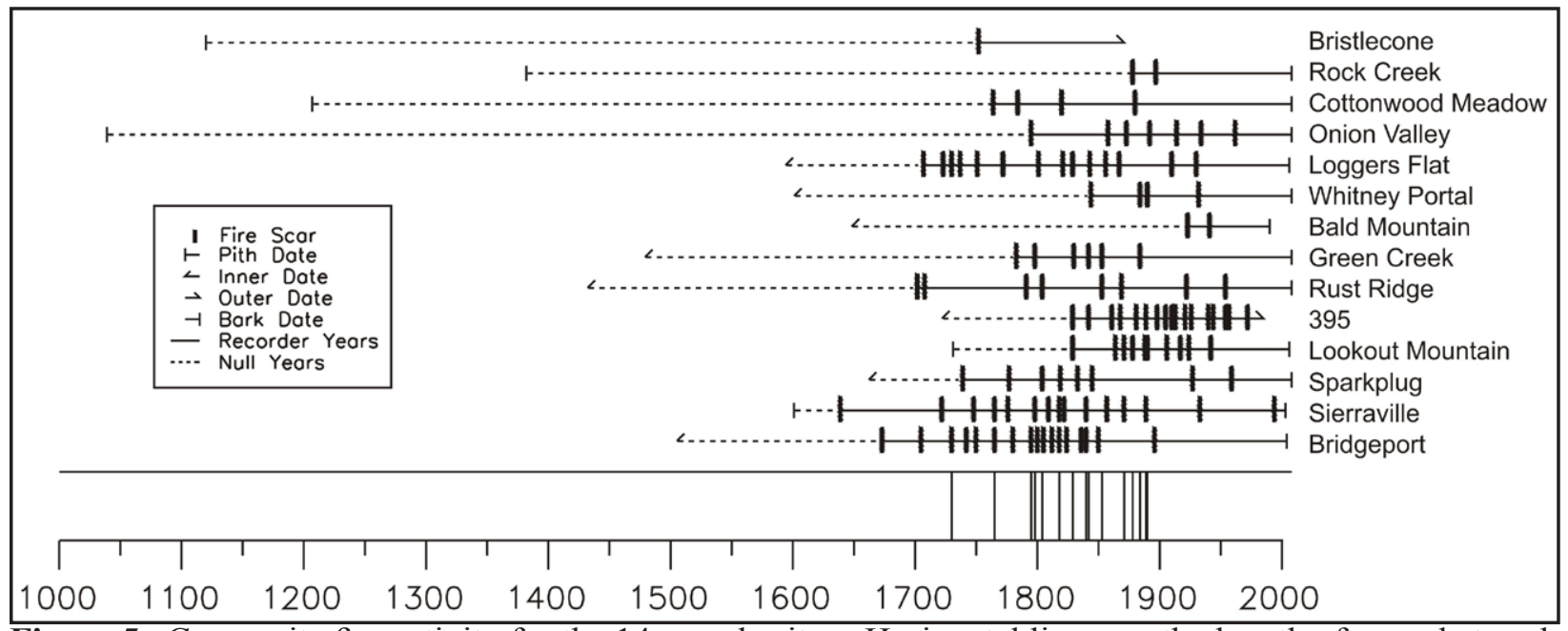

Figure 5. Composite fire activity for the 14 sample sites. Horizontal lines are the length of record at each sample site with vertical ticks indicating years when two or more trees were scarred. The composite record at the bottom indicates when two or more sites were scarred in the same year.

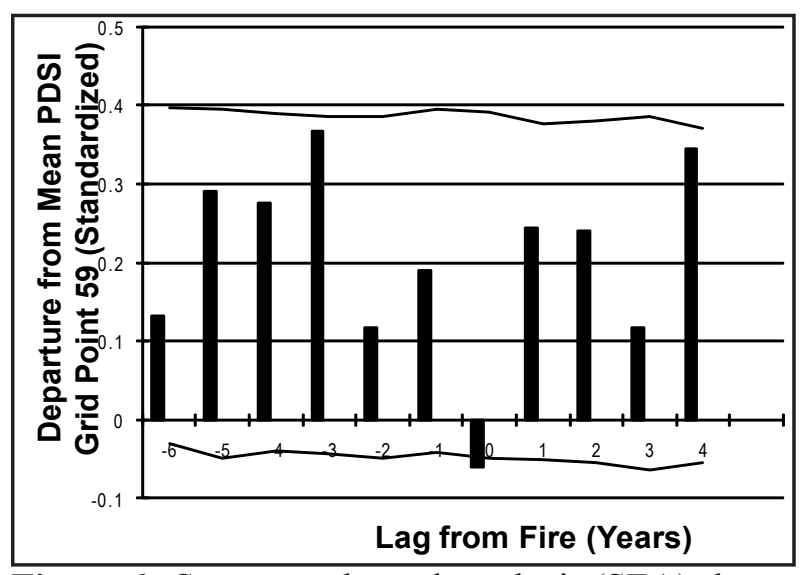

Figure 6. Superposed epoch analysis (SEA) showing departure from the mean Palmer Drought Severity Index values with years when fires scarred two or more trees at two or more sites. Horizontal lines are $99 \%$ confidence intervals.

was due to forest type rather than elevation. Our data also lend support to this hypothesis. Across our Jeffrey pine sample sites, there was no relation between site fire return interval and elevation. The highest Jeffrey pine site, Loggers Flat, which coincidentally occurred at nearly the same elevation as the foxtail pine at Onion Valley, had one of the lower site fire return intervals $(8.0 \mathrm{yr}$, see Table 1$)$. The four site fire return intervals (C1) for the foxtail, lodgepole and bristlecone pine sites (13.4 yr, $18.6 \mathrm{yr}, 27.2 \mathrm{yr}$, and $45.7 \mathrm{yr}$ ) demonstrate that although fire does occur regularly in these high-elevation forests, the observed variation in fire return intervals may be affected by more factors than elevation and dominant forest type. Although our data did not allow us to test these possibilities, we observed differences in site productivity and its associated effects on surface fuel production that may help explain site differences in fire return intervals.

We found that the predominant seasonality of historical fires, inferred from intra-ring scar position, for most eastern Sierra Nevada fires was similar to that reported in previous studies throughout the western Sierra Nevada. The majority of western fires occur between August and the onset of fall rain or snow. Our data suggest a similar pattern may also occur east of the crest. Fuels on both sides of the Sierra Nevada have similar drying cycles, in which they are saturated shortly after snowmelt but quickly dry during the summer drought (van Wagtendonk et al. 1998). Twentieth century climate data (Powell and Klieforth 2000) suggest the eastern Sierra Nevada occasionally receive more summer rain than the western slopes due to thunderstorms. These events, however, do not seem to have strongly influenced fire seasonality at the sites we sampled. 
Stand isolation of some of our Jeffrey pine sample sites may explain why the average C10 fire return interval for four sites (Rust Ridge, Loggers Flat, Sparkplug, and Whitney Portal ) of $28.2 \mathrm{yr}$ is longer than the average of $14.9 \mathrm{yr}$ for sites in larger contiguous forest stands. Two sample sites, Sparkplug (C10 of $31.4 \mathrm{yr}$ ) and Whitney Portal (29.3 yr), are stands within narrow, steep canyons, bordered by cliffs. Rust Ridge (36.0 yr) is in the large Jeffrey pine forest belt east of Mammoth Lakes, but is separated from the forest on three sides by large sand and pumice flats that lack fuels. Loggers Flat $(15.9 \mathrm{yr})$ is on a high ridge surrounded by sagebrush. In contrast, the other six Jeffrey pine sites are within larger forested areas. Some studies have found longer fire return intervals in isolated forest 'islands' compared to nearby larger forest 'mainlands' (Madany and West 1983, Grissino-Mayer and Swetnam 1995, Clarke 2002), while another (Arabas et al. 2006) found shorter fire intervals on forest stands isolated by lava flows. Arabas et al. (2006) suggests that topography, fuel continuity, soil type, and human activities can all influence fire spread, making it difficult to predict how isolated and mainland forest fire regimes compare without considering local conditions.

The absence of a common period of reduced fire activity at our sample sites may indicate differences in Native American customs and Euro-American settlement patterns between the western and eastern sides of the Sierra Nevada. Anthropological studies of the local Mono Indians suggest that they did not use fire to clear forest or increase browse for hunting (Blake and Wagner 1987, Lewis 1993) as did many Central Valley and Sierra Nevada western slope tribes (Anderson and Moratto 1996). In the western Sierra Nevada, a reduction in understory fuel from extensive sheep grazing may have contributed to the change in fire frequency at the end of the nineteenth century (Douglass and Bilbao 1975, Vankat and
Major 1978, Anderson 2005, Farquhar 2007). In the 1880s and 1890s in the eastern Sierra Nevada, cattle and sheep ranches were established to feed rapidly growing mining communities such as Bodie and Cerro Gordo (Wedertz 1969). Grazing, however, was largely limited to stream-fed meadows in the Owens Valley (Chalfant 1933). Without these broad-scale effects on ignitions and fuels, local patterns of settlement may explain some of our site-bysite differences in modern fire patterns. Roads to the three higher-elevation sites with modern records (Rock Creek, Cottonwood Meadow, and Onion Valley) were completed in the 1930s and 1940s, but no structures were built (Chalfant 1933, Smith 2003), and there was no apparent change in the fire regime. In contrast, fires at Whitney Portal virtually stop once the road from Lone Pine was completed in 1935 and structures are built at the road's end. Three sample sites record few fires (Green Creek, Sierraville) or no fires (Bridgeport) after the 1870 s and 1880s when mining and sawmill operations expanded in the northern half of the eastern Sierra Nevada.

The interesting exceptions to this pattern are the Bald Mountain, Rust Ridge, 395, and Lookout Mountain sites located within the extensive Jeffrey pine forest east of Mammoth Lakes. In general, the Jeffrey pine forests in this belt have a fairly low density and lighter surface fuel accumulations than western Sierra Nevada forests (Malcolm North, Forest Service, personal observation). All of these sites have active fire scar records into the 1950s. One possible cause for this high frequency is that this area has one of the highest concentrations of lightning strikes in the state (van Wagtendonk and Cayan 2008). A database for California fire perimeters (http://frap.fire.ca.gov/) indicates that fires have continued to burn in this area through the 1970s and 1980s. These variable modern fire patterns contrast with those of the western Sierra Nevada and many forests in the southwestern US, where fire 
events became rare following Euro-American settlement.

Summer drought conditions inferred from PDSI were significantly correlated with years in which fire occurred at two or more locations at sample sites near to and north of Mammoth Lakes. The Jeffrey pine forests east of Mammoth Lakes receive more precipitation than more southerly stands on the eastern slope because of a local low point in the Sierra Nevada crest (Hall 1991, Storer et al. 2004). More western slope precipitation crosses the Sierra Nevada at our northern sample sites (Figure 1) where the crest is lower (3600 m decreasing to $2600 \mathrm{~m}$ ) compared to our more southern sample sites (often $>4250 \mathrm{~m}$ ). The PDSI-identified drought years have been associated with years of widespread fire events in several studies on the western slope of the Sierra Nevada (Swetnam 1993, Swetnam and Baisan 2003) and in Nevada's Carson Range (Taylor and Beaty 2005). Although there are few weather stations east of the Sierra Nevada with long-term weather records (see http://cdec.water.ca.gov/), there was a significant correlation $\left(\mathrm{r}^{2}=0.58, p\right.$ $=0.04$ ) between PDSI values and total water year (July 1 through June 30) precipitation over the 24 yr record at a station, Rush Creek Powerhouse, nearest the Jeffrey pine belt east of Mammoth Lakes. Our study suggests that a PDSI correlation with years that have widespread fire events may also apply to eastside forests where the Sierra Nevada's rain shadow effect is reduced. Sites within the more pronounced rain shadow of the southern Sierra Nevada are likely dry enough to burn most summers, and may not require the drought conditions that other sites do to carry fire.

Our study suggests that eastern Sierra Nevada forest managers should consider forest type and local fire history when developing management prescriptions. Fire regimes and fuel loads in some high elevation lodgepole and foxtail pine forests may not have been extensively altered from historic conditions. Studies in other western forests have also found that geography and site history can produce widely varying fire histories even within the same forest type and fire regime (GrissinoMayer et al. 1995, Grissino-Mayer and Swetnam 1995, Swetnam and Baisan 2003, Taylor 2004). In contrast, some Jeffrey pine sites in our study (i.e., Green Creek, Bridgeport, and Sierraville) recorded fewer fire events in the twentieth century and likely support higher fuel loads than they did before the end of the nineteenth century. The most extensive eastern Sierra Nevada forest, the Jeffrey pine belt near Mammoth Lakes, maintained a frequent fire regime into the 1950s. This forest, however, was extensively thinned in the 1970s and 1980s (T. Higley, Inyo National Forest, personal communication), and any untreated slash could increase fuel loads and fire severity in the next burn. The history of frequent fire in our Jeffrey pine sites suggests that prescribed fire and wildland fire use would help restore and maintain lower fuel loads in these forests. Most of our sample sites had not yet developed the high fuel loads common in westside pine forests that often require mechanical thinning before prescribed fire can be applied (Ritchie and Skinner 2007). Managers may still have an opportunity to increase forest resilience to high-severity fire without incurring the substantial public controversy that often accompanies mechanical fuels treatments.

Eastern Sierra Nevada forests share some fire regime characteristics with western slope pine forests, such as fire return interval and seasonality, but sites have greater fire regime variability possibly due to stand isolation, local human-use history, and rain shadow conditions. 


\section{ACKNOWLEDGEMENTS}

We thank Dan Dawson and the Sierra Nevada Aquatic Research Lab for encouraging this study and providing a logistics base. We appreciate the reviews by Tom Swetnam and two anonymous reviewers, which greatly improved the manuscript. Tom Higley, John Louth, Michelle Slaton, and Margaret Wood of the Inyo National Forest helped identify potential sample stands and approved our collection of fire scar material. We appreciate Carl Skinner's assistance with the FHX2 software. Field sample collections were possible only with the help of Nikolai Barca-Hall, Domenico Caramagno, Marco Hille, Matt Hurteau, Lars Schmidt, Jaime Shields, Matt Smith, Don Stevens and Cristin Walters. Funding for this study was provided by the USDA Forest Service Pacific Southwest Research Station.

\section{LITERATURE CITED}

Anderson, M.K. 2005. Tending the wild: native American knowledge and the management of California's natural resources. University of California, Berkeley, USA

Anderson, M.K., and J.J. Moratto. 1996. Native American land-use practices and ecological impacts. Pages 187-206 in: Sierra Nevada Ecosystem Project, final report to Congress. Volume II, assessments and scientific basis for management options. University of California, Davis, Wildland Resources Center Report No. 37.

Arabas, K.B., K.S. Hadley, and E.R. Larson. 2006. Fire history of a naturally fragmented landscape in central Oregon. Canadian Journal of Forest Research 36: 1108-1120.

Arno, S.F., and K. M. Sneck. 1977. A method for determining fire history in coniferous forests of the mountain west. USDA Forest Service General Technical Report, INT-42. Ogden, Utah, USA.

Beaty, R.M., and A.H. Taylor. 2008. Fire history and the structure and dynamics of a mixed conifer forest landscape in the northern Sierra Nevada, Lake Tahoe Basin, California, USA. Forest Ecology and Management 255: 707-719.

Barbour, M., and J. Major. 1977. Terrestrial vegetation of California. John Wiley and Sons, New York, New York, USA.

Blake, E.A., and M.R. Wagner. 1987. Collection and consumption of pandora moth (Coloradia naddora lindseyi) larvae by Owens Valley and Mono Lake Paiutes. Bulletin of the Entomological Society of America 33: 22-27.

Caprio, A.C., and T.W. Swetnam. 1995. Historic fire regimes along an elevational gradient on the west slope of the Sierra Nevada, California. Pages 173-179 in: J.K. Brown, R.W. Mutch, C.W. Spoon, and R.H. Wakimoto, editors. Proceedings of the symposium on fire in wilderness and park management. USDA Forest Service General Technical Report INT-GTR-320. Ogden, Utah, USA.

Chalfant, W.A. 1933. The story of Inyo. 1975 reprint. Chalfant, Bishop, California, USA.

Clarke, P.J. 2002. Habitat islands in fire-prone vegetation: do landscape features influence composition? Journal of Biogeography 29: 677-684.

Cook, E.R., D.M. Meko, D.W. Stahle, and M.K. Cleaveland. 1999. Drought reconstructions for the continental United States. Journal of Climate 12: 1145-1162. 
Cook, E.R. 2000. Niño 3 index reconstruction. International Tree-Ring Data Bank. IGBP PAGES/World Data Center-A for Paleoclimatology Data Contribution Series \#2000-052. NOAA/NGDC Paleoclimatology Program, Boulder Colorado, USA. <http://www.ncdc.noaa. gov/paleo/recons.html>. Accessed 10 May 2009.

Dieterich, J.H. 1980. The composite fire interval - a tool for more accurate interpretation of fire history. Pages 8-14 in: M.A. Stokes and J.H. Dieterich, technical coordinators. Proceedings of the fire history workshop. USDA Forest Service General Technical Report RM-81. Fort Collins, Colorado, USA.

Elliott-Fisk, D.L., and A.M. Peterson. 1991. Trees. Pages 87-107 in: C.A. Hall, Jr., editor. Natural history of the White-Inyo Range, eastern California. University of California, Berkeley, USA.

Dieterich, J.H., and T.W. Swetnam. 1984. Dendrochronology of a fire scarred ponderosa pine. Forest Science 30(1): 238-247.

Douglass, W.A., and J. Bilbao. 1975. Amerikanuak: Basques in the new world. University of Nevada, Reno, USA.

Farquhar, F.P. 2007. History of the Sierra Nevada. University of California Press, Berkeley, USA.

Grissino-Mayer, H.D., C.H. Baisan, and T.W. Swetnam. 1995. Fire history in the Pinaleno Mountains of southeastern Arizona: effects of human-related disturbances. Pages 399-407 in: L.H. Debano DeBano, P.H. Ffolliott, A. Ortega-Rubio, G.J. Gottfried, R.H. Hamre., and C.B. Edminster, technical coordinators. Biodiversity and management of the Madrean Archipelago: the sky islands of southwestern United States and northwestern New Mexico. USDA Forest Service General Technical Report RM-GTR-264. Ogden, Utah, USA.

Grissino-Mayer, H.D., and T.W. Swetnam. 1995. Effects of habitat diversity on fire regimes in El Malpais National Monument, New Mexico. Pages 195-200 in: J.K. Brown, R.W. Mutch, C.W. Spoon, and R.H. Wakimoto, technical coordinators. Proceedings: symposium on fire in wilderness and park management. USDA Forest Service General Technical Report INT320:195-200. Ogden, Utah, USA.

Grissino-Mayer, H.D. 2001. FHX2: software for the analysis of fire history from tree rings. TreeRing Research 57: 113-122.

Grissino-Mayer, H.D., and T.W. Swetnam. 2000. Century-scale climate forcing of fire regimes in the American southwest. Holocene 10: 213-220.

Hall, C.A., Jr. 1991. Natural history of the White-Inyo Range, eastern California. University of California Press, Berkeley, USA.

Heyerdahl, E.K., D. McKenzie, L.D. Daniels, A.E. Hessl, J.S. Littell, and N.J. Mantua. 2008. Climate drivers of regionally synchronous fires in the inland northwest (1651-1900). International Journal of Wildland Fire 17: 40-49.

Johnson, D., W.W. Miller, R.B. Susfalk, J.D. Murphy, R.A. Dahlgren, and D.W. Glass. 2009 Biogeochemical cycling in forest soils of the eastern Sierra Nevada Mountains, USA. Forest Ecology and Management 258: 2249-2260.

Kitzberger, T., P.M. Brown, E.K. Heyerdahl, T.W. Swetnam, and T.T. Veblen. 2007. Contingent Pacific-Atlantic ocean influence on multi-century wildfire synchrony over western North America. Proceedings of the National Academy of Sciences 104(2): 543-548.

Kilgore B.M., and D. Taylor. 1979. Fire history of a sequoia mixed conifer forest. Ecology 60: 129-142. 
Lewis, H.T. 1993. Patterns of Indian burning in California: ecology and ethnohistory. Pages 55116 in: T.C. Blackburn and M.K. Anderson, editors. Before the wilderness: native Californians as environmental managers. Ballena, Menlo Park, California, USA.

Madnay, M.H., and N.W. West. 1983. Livestock grazing - fire regime interactions within montane forests of Zion National Park, Utah. Ecology 64: 661-667.

Martin, R.E., H.E. Anderson, and W.D. Boyer. 1979. Effects of fire on fuels: A state-of-knowledge review. USDA Forest Service General Technical Report WO-13. Washington, D.C., USA.

McKelvey K.S., and K.K. Busse. 1996. Twentieth century fire patterns on Forest Service lands. Pages 1119-1138 in: Sierra Nevada Ecosystem Project, final report to Congress. Volume II, assessments and scientific basis for management options. University of California, Davis, Wildland Resources Center Report No. 37.

McKelvey, K.S., C.N. Skinner, C Chang, D.C. Erman, S.J. Husari, D.J. Parsons, J.W. van Wagtendonk, and P.C. Weatherspoon. 1996. An overview of fire in the Sierra Nevada. Pages 1033-1040 in: Sierra Nevada Ecosystem Project, final report to Congress. Volume II, assessments and scientific basis for management options. University of California, Davis, Wildland Resources Center Report No. 37.

Millar, C.I., and W.B. Woolfenden. 1999. The role of climate change in interpreting historical variability. Ecological Applications 9: 1207-1216.

Miller C., and D.L. Urban. 1999. Forest pattern, fire, and climatic change in the Sierra Nevada. Ecosystems 2(1): 76-87.

Moody, T.J., J. Fites-Kaufman, and S.L. Stephens. 2006. Fire history and climate influences from forests in the northern Sierra Nevada, USA. Fire Ecology 2(1): 115-141. doi: 10.4996/ fireecology.0201115

Norman, S.P., and A.H. Taylor. 2003. Tropical and north Pacific teleconnections influence fire regimes in pine-dominated forests of north-eastern California, USA. Journal of Biogeography 30: 1081-1092.

North, M., M. Hurteau, R. Fiegener, and M. Barbour. 2005. Influence of fire and El Niño on tree recruitment varies by species in Sierran mixed conifer. Forest Science 51(3): 187-197.

Pitcher, D.C. 1987. Fire history and age structure in red fir forests of Sequoia National Park, California. Canadian Journal of Forest Research 17(7): 582-587.

Powell, D., and J. Klieforth. 2000. Weather and climate. Pages 70-93 in: G. Smith, editor. Sierra east: edge of the Great Basin. University of California, Los Angeles, USA

Pyne, S.J. 1982. Fire in America: a cultural history of wildland and rural fire. Princeton University, New Jersey, USA.

Ritchie, M.W., and C.N. Skinner. 2007. Probability of tree survival after wildfire in an interior pine forest of northern California: effects of thinning and prescribed fire. Forest Ecology and Management 247: 200-208.

Skinner, C.N., and C. Chang. 1996. Fire regimes, past and present. Pages 1041-1069 in: Sierra Nevada Ecosystem Project, final report to Congress. Volume II, assessments and scientific basis for management options. University of California, Davis, Wildland Resources Center Report No. 37.

Skinner, C.N., J.H. Burk, M. Barbour, E. Franco-Vizcaino, and S.L. Stephens. 2008. Long-term influences of climate on fire regimes in montane forests of northwestern Mexico. Journal of Biogeography 35(8):1436-1451. 
Smith, R.M. 2003. Mono County. Progressive Graphic Publishing, Ware, Massachusetts, USA.

Stephens, S.L. 2001. Fire history differences in adjacent Jeffrey pine and upper montane forests of the eastern Sierra Nevada. International Journal of Wildland Fire 10: 161-167.

Stephens, S.L., and B.M. Collins. 2004. Fire regimes of mixed conifer forests in the north-central Sierra Nevada at multiple spatial scales. Northwest Science 78: 12-23.

Stephens, S.L., and J.J. Moghaddas. 2005. Experimental fuel treatment impacts on forest structure, potential fire behavior, and predicted tree mortality in a mixed conifer forest. Forest Ecology and Management 215: 21-36.

Stokes, M.A., and T.L. Smiley. 1977. An introduction to tree-ring dating. University of Chicago, Illinois, USA.

Storer, T.I., R.L. Usinger, and D. Lukas. 2004. Sierra Nevada natural history. University of California, Berkeley, USA.

Swetnam, T.W. 1993. Fire history and climate change in sequoia groves. Science 262: 885-889.

Swetnam T.W., C.H. Baisan, M. Morino, and A.C. Caprio. 2000. Fire history along elevational transects in the Sierra Nevada, California. Final report to Sierra Nevada Global Change Research Program, United States Geological Survey, Biological Resources Division, Sequoia, Kings Canyon, and Yosemite National Parks. University of Arizona, Tucson, USA.

Swetnam, T.W., and C.H. Baisan. 2003. Tree ring reconstructions of fire and climate history in the Sierra Nevada and southwestern United States. Pages 158-195 in: T.T. Veblen, W.L. Baker, G. Montenegro, and T.W. Swetnam, editors. Fire and climatic change in temperate ecosystems of the western Americas. Ecological studies 160. Springer-Verlag, New York, New York, USA.

Taylor, A.H. 1993 Fire history and structure of red fir (Abies magnifica) forests, Swain Mountain experimental forest, Cascade Range, northeastern California. Canadian Journal of Forest Research 23:1672-1678.

Taylor, A. 2004. Identifying forest reference conditions on early cut-over lands, Lake Tahoe Basin, USA. Ecological Applications 14: 1903-1920.

Taylor, A.H., and R.M. Beaty. 2005. Climatic influences on fire regimes in northern Sierra Nevada mountains, Lake Tahoe Basin, Nevada, USA. Journal of Biogeography 32: 425-438.

Vaillant, N.M., and S.L. Stephens. 2009. Fire history of a lower elevation Jeffrey pine-mixed conifer forest in the eastern Sierra Nevada, California, USA. Fire Ecology 5(3): 4-19. doi:10.4996/fireecology.0503004

van Wagtendonk J.W., J.M. Benedict, and W.M. Sydoriak. 1998. Fuel bed characteristics of Sierra Nevada conifers. Western Journal of Applied Forestry 13(3): 73-84.

van Wagtendonk, J.W., and D.R. Cayan. 2008. Temporal and spatial distribution of lightning strikes in California in relation to large-scale weather patterns. Fire Ecology 4(1): 34-56. doi: 10.4996/fireecology.0401034

Vankat, J.L., and J. Major. 1978. Vegetation changes in Sequoia National Park, California. Journal of Biogeography 5: 377-402.

Weaver, R.A., and M.E. Basgall. 1986. Aboriginal exploitation of pandora moth larvae in eastcentral California. Journal of California and Great Basin Anthropology 8: 161-179.

Wedertz, F.S. 1969. Bodie 1859-1900. Chalfant, Bishop, California, USA. 